\title{
VIOLÊNCIA, PODER E DEMOCRACIA: NOTAS SOBRE A RELAÇÃO ENTRE DEMOCRACIA E MONOPÓLIO ESTATAL
}

\author{
Fernando Cesar Mendes Barbosa ${ }^{1}$ \\ José Mauro Garboza Junior ${ }^{2}$
}

\begin{abstract}
Resumo: O presente artigo constitui uma análise a respeito da relação entre democracia e o monopólio estatal do direito e da violência. Objetiva-se investigar a maneira pela qual violência, poder (ARENDT, 2007; 2018), democracia e Estado (BOBBIO, 1999; 2000; 2006; 2013) estão relacionados. Parte-se de uma análise do problema democrático contemporâneo, para compreender, a partir da História do Direito (HESPANHA, 2005; 2016), como democracia e legitimidade definem-se pelo estabelecimento de verdadeiras relações de força. A partir dos métodos dialético e bibliográfico, conclui-se apontando para a necessidade de retomada dos valores democráticos na construção de uma sociedade mais justa.
\end{abstract}

Palavras-chave: Estado; Democracia; Violência; Poder; Monopólio

\section{VIOLENCE, POWER AND DEMOCRACY: NOTES ON THE RELATIONSHIP BETWEEN DEMOCRACY AND STATE MONOPOLY}

\begin{abstract}
This article analyzes the relation between democracy and the State monopoly of law and violence. Its objective is to investigate the way in which violence, power (ARENDT, 2007, 2018), democracy and State (BOBBIO, 1999; 2000; 2006; 2013) are related. The contemporary democratic problem is analysed, from the History of Law (HESPANHA, 2005; 2016), to understand how democracy and legitimacy are defined by the establishment of relations of force. From the dialectical and bibliographic methods, it concludes by pointing to the need of a resumption of democratic values in the construction of a more just society.
\end{abstract}

Keywords: State; Democracy; Violence; Power; Monopoly

\section{INTRODUÇÃO}

\footnotetext{
${ }^{1}$ Advogado. Mestre em Ciência Jurídica pela Universidade Estadual do Norte do Paraná - UENP. Possui Licenciatura em Letras. Atualmente é servidor da Universidade Federal da Integração LatinoAmericana. É Pesquisador do Grupo de Pesquisa BIOTEC - Direito, Biotecnologia e Sociedade, da Universidade Federal do Paraná. fernandocesarmb@gmail.com

${ }^{2}$ Mestre em Ciência Jurídica pela Universidade Estadual do Norte do Paraná - UENP. Graduação em Ciências Sociais (Licenciatura Plena) pela Universidade Metropolitana de Santos (UNIMES), graduação em Direito pela Universidade Estadual do Norte do Paraná (UENP), graduação em História pela Universidade Metropolitana de Santos (UNIMES), é membro coordenador do coletivo Círculo de Estudos da Ideia e da Ideologia (CEII). garbozajm@gmail.com
} 
Fernando Cesar Mendes Barbosa \& José Mauro Garboza Junior

Por mais que pareçam claras, aos olhos dos juristas as distinções entre violência, poder e democracia parecem confundir no mais das vezes suas linhas de fronteira. Pensadas particularmente, cada uma dessas partículas contêm em si características tais que nos permitem pensá-las apenas e tão somente em sua interação simultânea. Isso se dá, e é o que se quer defender neste trabalho, pela excedente carga valorativa que o Estado tem para esses papéis.

Se hoje a violência aparece cada vez mais escancarada e normalizada, tem-se a impressão de que algo funciona mal. Se a democracia pode ser colocada em xeque por algumas de suas próprias instituições, algo parece não funcionar. E se o poder perde sua aura de autoridade e legitimidade, a dissintonia parece reinar. Sendo assim, caberia ao Estado assumir a tarefa de restituí-los ao estágio em que os problemas não haviam surgido? Será ele onipotente a ponto de resolvê-lo? Ou seria mais interessante pensarmos formas outras que passam ao lado daquelas formações estatais clássicas?

No primeiro momento, apresentaremos alguns comentários a respeito da violência a partir das considerações feitas por Hannah Arendt. Trata-se de mostrar, ao lado do poder legítimo, a violência como um fator político que deve ser distanciado sob pena de existência da própria política. Além disso, ao mesmo tempo em que se compreende a violência e o poder como instituições antagônicas, também se torna possível uma abordagem sobre “convergências" ou “aproximações" entre a violência e o poder.

No segundo momento, queremos fazer uso das lições da história do direito de António Manuel Hespanha para problematizar a questão da estatalidade e das relações de poder que constituem as narrativas históricas. A partir disso, queremos apontar que as interpretações feitas do Direito ao longo do tempo poderiam nos indicar para modos dentro dos quais disputas hermenêuticas estariam em jogo em uma pluralidade. Também se quer com isso apontar para o caráter extraestatal que o Direito possui e que pode, a partir disso, continuar possuindo com maior força.

No terceiro momento, buscaremos apresentar as tensões políticas entre o constitucionalismo e a democracia. Ambos como espaços de disputa em torno da legitimidade e legalidade para a conquista da direção política. Além disso, perceber como é possível disputar tais espaços tanto dentro do estado pelas funções administrativas, burocráticas e legislativas quanto fora dele (isto é, pela sociedade civil). 
Por fim, o que se verifica é que democracia, Estado de direito e legitimidade, são realidades que se relacionam diretamente na compreensão da relação que se estabelece entre Estado e indivíduos e marcam um processo de construção sócio-histórico que, interpretado pela história do direito, evidencia relações de força que lutam na definição e no estabelecimento do poder, ou do monopólio ou da violência. É nesse sentido que quando se compreende o poder como uma propriedade, abre-se a possibilidade para que a violência o destitua, fragilizando a ideia de consenso, a ideia de "comum" e a própria ideia de poder. É a análise das diversas relações de poder que se relacionam na história que apontam para a necessidade de compreensão da função política do direito ressignificada para além do monopólio estatal do direito (e da violência), reafirmando a necessidade do reconhecimento de critérios supralegais para sua legitimidade.

Em termos de metodologia, o presente artigo possui como objetivo estabelecer uma reflexão a respeito da relação entre violência, poder e democracia e a maneira pela qual essas realidades se relacionam com o monopólio estatal do direito e da violência. Parte-se de uma análise do problema democrático contemporâneo que tem, sobretudo recentemente, apresentado "novas leituras" à democracia, para compreender, a partir da história do direito, como democracia e legitimidade definem-se pelo estabelecimento de verdadeiras relações de força. Assim, entre os temas centrais do artigo estão a democracia e a legitimidade, explorados a partir dos métodos dialético e bibliográfico.

\section{SOBRE A VIOLÊNCIA EM HANNAH ARENDT}

Pensar as diversas maneiras pelas quais podemos nos relacionar com a violência tem sido uma prática cada vez mais recorrente, sobretudo em razão de modelos democráticos estarem sendo colocados à prova em tempos nos quais as novidades políticas radicais parecem tomar o lugar das antigas preferências.

Em uma tentativa questionável de conciliar anseios populares com os princípios democráticos e, especificamente em democracias como a brasileira, desafios têm sido apresentados aos modelos democráticos vigentes por meio de uma agenda que não se reveste, necessariamente, de princípios democráticos, apontando para relações extremamente marcadas pelo que Hannah Arendt (2018) classifica como uma relação entre poder e violência e que pode apontar para uma das características dessa nova fase de "ressignificação" democrática ou ao menos do que se convencionou chamar de democracia. 
Fernando Cesar Mendes Barbosa \& José Mauro Garboza Junior

Se por um lado, "eventos" ou "acontecimentos" marcados pela violência ou por violências estimulam, em certa medida, os interesses para que se voltem às possíveis relações que podem ser estabelecidas por meio dela, por outro, há também uma discussão que se coloca no âmbito das relações com "o espaço público", local no qual também são estabelecidas relações com a violência ou com formas de violência. (FRASER, 1990; HABERMAS, 2014). Essas relações que são estabelecidas pela presença ou pelo diálogo da violência com o "espaço público" também passam pela maneira pela qual se justifica ou se legitima a violência.

A esse respeito, de acordo com a filosofia política de Hannah Arendt, "a violência pode ser justificável, mas nunca será legítima” (2018, p. 69). Se mesmo naqueles casos nos quais o uso da violência pode ser "permitido" ou "autorizado", como é o caso da legítima defesa, por exemplo, em que esse uso pode ser justificável, ele jamais será legítimo. Legitimidade é uma categoria que não encontra amparo na violência, mas justamente aquela que se localiza no anverso desta em termos políticos e sociais - onde há legitimidade, carece a violência.

Em uma espécie de uso impróprio às lições de Max Weber (1999), a respeito da distinção entre dominação legítima (poder) e dominação ilegítima (violência), é bem provável que Arendt tenha se baseado nisso para constituir as linhas diretivas de seu debate, a este do Estado como detentor do monopólio da violência (WEBER, 1999, p. 161). Como detentor absoluto da violência, o Estado seria, para Weber, o único ente capaz de transformar as mais variadas formas de violências em vontade legítima dos pontos de vista tradicionalista (dominação tradicional), do ponto de vista afetivo (dominação carismática) e do ponto de vista lógico-racional com relação aos fins e aos valores (dominação administrativo-burocrática. Mesmo que haja uma herança weberiana, as análises de Arendt parecem indicar para uma reformulação menos antagônica desses dois polos.

Para Arendt, a legitimidade é marca característica do poder que, dialogicamente oposto à violência, constitui-se em nome de um "consenso", em nome de uma suposta "legitimidade". Assim, "O poder não precisa de justificação, sendo inerente à própria existência das comunidades políticas; o de que ele realmente precisa é legitimidade" (ARENDT, 2018, p. 69). É dessa relação que se depreende que o poder quando instaurado se reveste da condição de legítimo, ao passo que a violência deverá ser no máximo justificável. 
A esse mesmo respeito, equivaleria dizer, nos termos da filosofia política de Norberto Bobbio, um verdadeiro "poder em público”, sobretudo porque para ele “(...) essa definição capta muito bem um aspecto pelo qual a democracia representa uma antítese de todas as formas autocráticas de poder" (BOBBIO, 2000, p. 387).

Dessa maneira, não apenas aqueles eventos que equivocadamente são caracterizados como atos isolados de violência - por que um ato de violência jamais será isolado, seus efeitos se ampliam e enfraquecem o poder - como uma mulher que é brutalmente violentada e tem sua vida narrada em dezenas de noticiários ou como práticas de terror disseminadas em ambientes coletivos, como escolas ou lugares públicos congêneres, tampouco como práticas institucionalizadas de apologia ao uso de armas como forma de combate à criminalidade ou de fortalecimento à segurança pública, como se, de alguma maneira, a violência pudesse ser mecanismo de construção de segurança ou de qualquer outro "bem jurídico tutelável”.

Contrariamente, o que se verifica é que de práticas de violência sobrevém o enfraquecimento de construções coletivas e de consenso, na concepção arendtiana do termo. Para além disso, o que tem se tornado possível verificar é que a vida em sociedade e a violência guardam relação muito mais direta do que os citados exemplos que, corriqueiramente, e mais recentemente, têm chamado a atenção e podem, inclusive, caminhar para uma "naturalização" de condutas violentas que jamais deveriam ser "naturalizadas”. Desse modo “(...) a prática da violência, como toda a ação, muda o mundo, mas a mudança mais provável é para um mundo mais violento" (ARENDT, 2011, p. 58). É por meio da noção arendtiana de violência que se considera que esse uso indiscriminado da violência, de certa forma, conduz a uma "banalização", no sentido de naturalização, da violência ou de práticas de violência, que podem ser diretas ou indiretas.

Nesse sentido, formas de apologia à violência, diretas ou indiretas, veladas ou explícitas, sejam elas pelo incentivo ou defesa ao uso de armas, sejam por práticas "institucionais" que pregam sociedades culturalmente hegemônicas, precisam ser analisadas com cuidado, principalmente por que se constituem em práticas que extrapolam o âmbito das relações privadas (e ainda que não extrapolassem seriam temerárias) e se manifestam no bojo das relações sociais, demarcando, em certa medida, as relações entre os próprios membros de uma determinada comunidade, mas também e, principalmente, entre os membros de uma comunidade e o Estado. 
Para Hannah Arendt, as relações que são estabelecidas pela violência, e por meio dela, precisam ser pensadas a partir da ideia de poder, de forma que, para ela, a violência e o poder guardam entre si, uma estreita relação de interdependência, esclarecendo que "o poder emerge onde quer que as pessoas se unam e ajam em concerto, mas sua legitimidade deriva mais do estar junto inicial do que de qualquer ação que então se possa seguir”. (2018, p. 69).

Uma análise sobre a instrumentalidade (e institucionalidade) do uso da violência está no pensamento de Walter Benjamin, ao analisar a relação de instrumentalidade que se estabelece entre o direito e a violência. Tal como Weber se choca com a concepção arendtiana, Benjamin também se mostra como um estratégico interlocutor:

na instauração do direito tem um função dupla, no sentido de que a instauração do direito almeja como seu fim, usando a violência como meio, aquilo que é instaurado como direito, mas no momento da instauração não abdica da violência; mais do que isso, a instauração constitui a violência em violência instauradora do direito - num sentido rigoroso, isto é, de maneira imediata, pois estabelece não um fim livre e independente de violência (Gewalt), mas um fim necessário e intimamente ligado a ela, e o instaura enquanto direito sob o nome de poder (Macht). A instauração do direito é instauração do poder e, enquanto tal, um ato de manifestação imediata da violência (BENJAMIN, 2011, p. 148).

Esse uso instrumental da violência na instauração e na manutenção do direito, chocase, inicialmente, com a ideia de consenso apresentada por Hannah Arendt, para quem uma das características mais importantes do poder e das relações que a partir dele são estabelecidas é justamente o "ponto comum", o consenso entre os membros de uma comunidade. É como se em nome de um grupo, de uma coletividade, e para agir em nome desse grupo, um poder fosse legitimado, instituído: "Sob condições de um governo representativo, supõe que o povo domina aqueles que o governam. Todas as instituições políticas são manifestações e materializações do poder; elas se petrificam e decaem tão logo o poder vivo do povo deixa de sustentá-las" (ARENDT, 2018, p. 57).

À diferença de Benjamin, para quem a violência não é senão o próprio direito, ao perceber a racionalidade operativa da violência como um "desvio" do jurídico e consequentemente um desvio do horizonte equivalente de liberdades promovidos pelas democracias, Arendt não pode concordar com a visão ampla filosófica de que "direito é violência" (BENJAMIN, 2011), restando-lhe assumir uma perspectiva mais temperada dos 
termos. Dessa forma, as possibilidades de uso instrumentalizado da violência, inclusive na fundação e manutenção do próprio direito, apontam para uma concepção que se filia aos princípios liberais na formação da ideia de consenso em Hannah Arendt.

Essa estreita relação entre consenso, legitimidade e poder ao mesmo tempo em que fortalece o poder como uma ação consensual, ou melhor, coletiva, em nome de um grupo, também se relaciona à ideia de violência, sobretudo em razão de, na violência estar ausente a ideia de coletividade e de consenso, materializando-se em uma verdadeira inversão de polos, nos quais não mais um grupo fortalece e legitima a atuação de "um" ou de "alguém", mas "um" ou "alguém" se volta ao coletivo por meio da prática de ações de violência, é por isso que, "a tirania (...) é portanto a mais violenta e menos poderosa das formas de governo" (ARENDT, 2018, p. 58), apontando para outros usos "distorcidos" do consenso, como sua condução à tirania. Assim, o consenso também coage os participantes e elimina as alternativas da política, elimina os riscos da política, ou, pior ainda, elimina a própria política da política.

Nessa teia de contraposições entre os fundamentos do poder e os usos que são feitos da violência, também se aponta para elementos importantes para a compreensão da maneira pela qual governos de Estados se relacionam com a coletividade, sobretudo quando consideradas as ações que se destinam ao fortalecimento do coletivo, seja por meio da implementação de políticas públicas que visem ampliar o acesso a direitos ou pela criação de condições que visem melhorar a condição de vida da população. Esses são indícios que podem sinalizar para ações governamentais que estejam voltadas a referendar a legitimidade outrora concedida ou ao contrário, afastá-la.

o poder corresponde à habilidade humana não apenas para agir, mas também para agir em concerto. O poder nunca é propriedade de um indivíduo; pertence a um grupo e permanece em existência apenas enquanto o grupo se conserva unido. Quando dizemos que alguém está "no poder", na realidade nos referimos ao fato de que ele foi empossado por um certo número de pessoas para agir em seu nome. (ARENDT, 2018, p. 61).

Assim, quando o poder deixa de ser compreendido como titularidade de um grupo e passa a ser tomado como "propriedade", a legitimidade se esvai e o caminho da violência se abre, de maneira que “(...) cada diminuição no poder é um convite à violência pelo menos por que aqueles que detêm o poder e o sentem escapar de suas mãos, sejam eles os governantes, sejam os governados, têm sempre achado difícil resistir à tentação de substituí-lo pela violência" (ARENDT, p. 108). Nesse sentido, o problema que se coloca é que todo o poder é 
Fernando Cesar Mendes Barbosa \& José Mauro Garboza Junior

compreendido em algum momento como propriedade, principalmente, como se tem visualizado mais recentemente na sociedade brasileira, em questões jurídicas e político-eleitorais.

Essa substituição do poder pela violência ocorre à medida que a representatividade, ou melhor, a legitimidade do "escolhido", do "legitimado" para atuar em nome do grupo diminui, o que também pode estar associado à perda ou à diminuição das expectativas depositadas - nas democracias - em um candidato eleito, que não consegue ou não tem capacidade para atender aos anseios daqueles que lhe conferiram legitimidade.

Eventuais processos de diminuição do poder e aumento da violência, ou mesmo da "troca" daquele por esta evidenciam que "o domínio pela pura violência advém de onde o poder está sendo perdido. (...) substituir o poder pela violência pode trazer a vitória, mas o preço é muito alto; pois ele não é pago só pelo vencido, mas também pelo vencedor, em termos de seu próprio poder". (ARENDT, 2018, p. 71). A ideia de consenso, associada à concepção de legitimidade, que se materializa na "concessão", na instituição do poder reveste-se também da necessidade de compreensão acerca daquilo que é público, ou seja, que pertence a uma coletividade. (ARENDT, 2007, p. 60-61).

Quando as atividades relacionadas ao uso do poder se distanciam do coletivo, do público, características fundamentais para legitimá-lo, aproximam-se da violência, o que leva a concluir que "Esperar de pessoas que não têm a menor noção acerca do que é a res publica, a coisa pública, que se comportem de maneira não violenta e discutam racionalmente em questões de interesse não é realista nem razoável” (ARENDT, 2018, p. 98). A razoabilidade da qual se fala caminha para o entendimento que o consenso necessário a ideia de poder não se manifesta, ou ao menos não deveria, apenas na instituição ou na atribuição de legitimidade, mas sobretudo e principalmente, na forma pela qual esse poder "recebido" das mãos da coletividade é utilizado.

Também se depreende que o uso do poder na administração da coisa pública e dos interesses coletivos deverá ser o mais isento de violência possível, em razão de que na ausência de violência ou de imposições arbitrárias à revelia da comunidade, uma ação mais racional pode ter espaço e atender aos objetivos primeiros e consensuais da atribuição de poder.

A partir das concepções políticas de Hannah Arendt, não se trata de advogar por uma ação do governante - que recebeu o poder da comunidade - totalmente isenta ou distante da violência ou de formas de violência. O que se tem é que apesar da afirmação de que "a violência sempre pode destruir o poder" (ARENDT, 2018, p. 70), há uma linha de aproximação, por meio 
da qual se estabelece que quanto mais próximo da violência - aqui compreendida sobretudo como ausência de consenso - as práticas do governante se aproximarem, menos legitimidade e menos "força", menos "poder" estarão presentes. Para além disso, Arendt também destaca que “(...) nada é mais comum do que a combinação de violência e poder, nada é menos frequente do que encontrá-los em sua forma pura e, portanto, extrema”. (2018, p. 63). É em razão disso que para ela, "poder e violência, embora sejam fenômenos distintos, usualmente aparecem juntos". (2018, p. 69).

O fato de se conceber que poder e violência guardam entre si uma relação de "proximidade" não significa necessariamente, uma relação de naturalidade. Contrariamente, a relação que se estabelece é muito mais de arbitrariedade do que de complementariedade. Poder e violência não são os mesmos e mais que isso, como dito acima, a violência pode destruir o poder, o "consenso", o "legítimo" e a própria ideia de corpo comum tão cara à noção de poder. Nesse sentido,

Politicamente falando, é insuficiente dizer que poder e violência não são o mesmo. Poder e violência são opostos; onde um domina absolutamente, o outro está ausente. A violência aparece onde o poder está em risco, mas, deixada a seu próprio curso, conduz à desaparição do poder. Isso implica ser incorreto pensar o oposto da violência como a não violência; falar de um poder não violento é de fato redundante. A violência pode destruir o poder; ela é absolutamente incapaz de criá-lo (ARENDT, 2018, p. 74).

Se a violência é incapaz de criar o poder, tampouco de sustentá-lo, essa relação que se contrapõe entre ela e o poder aponta para os perigos de uma "intromissão" da violência na política - compreendida como o ato de gerir a coisa pública - esse perigo reside principalmente no fato de que uma eventual "monopolização do poder causa o ressecamento ou o esgotamento de todas as fontes autênticas de poder no país". (ARENDT, 2018, p. 106), bem como a estreita relação entre violência e direito, apontando para a instrumentalidade do uso da violência na manutenção do direito (BENJAMIN, 2011, p. 148).

Essa compreensão que, em apertada síntese, demonstra uma certa contraposição entre poder e violência materializa-se em uma imposição da violência à própria ideia de igualdade entre os membros de uma determinada comunidade, de um grupo, ou seja, o que se opera é a compreensão da violência não como uma manifestação do poder, mas como uma desconstrução do poder, reforçando a ideia e a compreensão de que violência e poder são institutos opostos, de forma que onde a violência estiver em sua forma plena não estará presente o poder, e o contrário também se aplica onde o poder se manifesta plenamente não se apresenta a violência. 
Fernando Cesar Mendes Barbosa \& José Mauro Garboza Junior

\section{HESPANHA \\ 2 HISTÓRIA E AS RELAÇÕES DE PODER EM ANTÓNIO MANUEL}

Os dilemas jurídicos contemporâneos, dado seu contexto altamente complexo e ainda em construção, mostram-se cada vez mais relacionados e dependentes de fontes históricas do direito, além de precisarem, cada vez mais, recorrerem à comparação e a essas fontes a fim de que desse exercício nasça algo novo que tente ao menos estabelecer um preenchimento das lacunas jurídicas contemporâneas. Tal é, em uma perspectiva histórica, a importância de se perceber a História do Direito para além de seu lugar academicamente estabelecido. Segundo António Manuel Hespanha, o historiador tem muitas tarefas para se engajar, muitas estratégias para pôr em prática:

A primeira estratégia deve ser a de instigar uma forte consciência metodológica nos historiadores, problematizando a concepção ingénua segundo a qual a narrativa histórica não é senão o simples relato daquilo que "realmente aconteceu". É que, de facto, os acontecimentos históricos não estão aí, independentes do olhar do historiador, disponíveis para serem descritos. (HESPANHA, 2005, p. 33-34).

Segundo o comentário, parece-nos impossível a construção de fatos históricos sem a influência do olhar do historiador como sua condição de nascimento. Os resgates possíveis por meio do fazer histórico para os estudos jurídicos são imprescindíveis. Contudo, com isso, não queremos dizer que estamos imersos em um mundo repleto de relativismos sem qualquer verificação das verdades históricas factuais.

Antes de tudo, o que se verifica é que a interpretação sobre os fatos (alguns inegáveis e outros nem tanto) podem ser costurados de modo a servir para o tempo presente do ato da costura. É impossível, portanto, independentemente do olhar do historiador, perceber uma narrativa isolada com o estatuto de verdade absoluta. É nesse sentido que se torna possível falarmos em diversas relações de poder que se relacionam no curso da história, entre as quais a relação entre violência e poder.

Dessa relação, entre violência e poder, da mesma forma, emerge a compreensão de que também há uma aproximação que se estabelece entre a observância ou o cumprimento às leis e ao consenso, de forma que essa observância às leis tem sua origem no próprio consentimento e não em uma ação inquestionável. Vale dizer que, mesmo se mantemos a diferenciação entre violência e poder, o material que os compõe simultaneamente é formado 
pelo emaranhado complexo das relações de poder, das microfísicas do poder (FOUCAULT, 1984, p. 99-112; 1987, p. 26-34).

Considerar a violência, o poder e o consenso como realidades interdependentes que se relacionam diretamente com o que tem sido chamado de democracia coloca em evidência que as formas de organização democrática de uma sociedade são estruturas muito mais complexas que a mera consideração da participação popular na tomada de decisão.

Contrariamente, os processos democráticos contemporâneos, como o brasileiro, por exemplo, são fortemente marcados por relações de poder, de violência e de interesses setoriais, interesses particularizados que, por um lado, corroem a noção de consenso legitimadora do poder, como vimos acima e, por outro, mostram o lado nocivo e perigoso que a inversão polarizada da ideia de consenso pode assumir.

Essas polaridades afetam diretamente a forma pela qual a sociedade se organiza frente à participação popular na administração do "espaço público", ao tempo em que também abrem caminho para a própria ressignificação do direito, não apenas como ação instrumentalizadora da violência, como apresentamos anteriormente (ARENDT, 2018; BENJAMIN, 2011; FRASER, 1990; HABERMAS, 2014), mas também como espaço de poder.

No entanto, a respeito dessa relação entre as leis e aqueles a quem elas se dirigem, António Manuel Hespanha (2005, p. 21-48; 2016, p. 34-35) destaca que não é suficiente apenas a afirmação que direitos, bem como, leis e obrigações tenham origem em consensos sociais e aponta para a necessidade do estabelecimento de critérios que sejam supralegais para a verificação da legitimidade de uma lei, que se fortalecem em uma ordem constitucional, em sentido material, por meios de instrumentos que viabilizem a democracia participativa, mas também deliberativa, além da valorização dos chamados direitos de resistência, frente ao direito positivo.

Também é nesse sentido que, para Hespanha (2016), a legitimidade do direito, ou melhor, a sua preservação, contemporaneamente, requer critérios que estão, em certa medida, além da capacidade do próprio Estado. Sem qualquer referência direta ao "extermínio" do Estado, aos traços eminentemente anarquistas ou às concepções favoráveis ao mercado, o que está em jogo nessa perspectiva é justamente a convocação de novos atores sociais para, junto com o Estado, participarem de maneira realmente efetiva, não apenas com caráter consultivo ou legitimador. As novas formas jurídicas precisam ser criadas mesmo que o Estado tenha que abdicar parte de suas forças para fazê-lo. Nessa direção, Hespanha considera, criticamente, que 
o direito não é uma coisa que exista por si e em si. Mas antes é algo que só existe porque alguém (algum grupo) fala dele, o designa, o refere, dando-lhe um determinado conteúdo e delimitando-lhe um determinado campo de aplicação no plano da prática social. Isto quer dizer que, para grupos diversos de interlocutores, pode haver diversos direitos. (2016, p. 8)

Se tanto a forma quanto o conteúdo do direito se dão intersubjetivamente e extraestatal, o pluralismo jurídico pode somente existir na medida em que as vozes em conjunto dos diversos atores se apresentem em um grau de equivalência tal que a simples omissão estatal não produza efeitos jurídicos anuláveis. É nesse mesmo sentido, que a orientação para uma sociedade plural pode ser uma das alternativas para resolver o enigma do contemporâneo. Para Hespanha,

pluralismo jurídico é antes de ser algo que surgiu nos nossos dias, por circunstâncias particulares dos tempos e das políticas, é antes algo de sempre, pois tem a ver com a maneira de ser dos próprios grupos humanos - a sua diversidade de maneiras de ver o mundo, as relações dele com os homens e as que os homens mantém entre si. Ibi societas, ibi iura (agora, no plural). (2016, p. 9).

Assim, dessa maneira, o desafio que se coloca reside na capacidade de compatibilização entre o pluralismo jurídico descrito por Hespanha e o princípio democrático, o que se apresenta sobretudo em razão de os Estados democráticos contemporâneos "ainda" terem pretensões democráticas, como é o caso do Brasil, por exemplo.

O poder de autonomia, controle e autodeterminação da organização provincial, regional, municipal e distrital nunca tomou forma e nunca se desenvolveu em nosso pseudofederalismo, porquanto a sociedade frágil, desorganizada e conflituosa sempre esteve à mercê, tanto de relações políticas calcadas no clientelismo, no coronelismo e nos privilégios cultivados pela dominação dos grandes proprietários de terras, quanto de atuações paternalistas, autoritárias e intervencionistas dos Estado. Sem sombra de dúvidas que o perfil extremamente débil das elites nacionais, subordinados aos intentos de acumulação das metrópoles, favorece a montagem de um Estado interventor e patrimonialista, capaz de controlar e imprimir grande centralização sobre a sociedade (WOLKMER, 2015, p. 292293).

As raízes brasileiras, marcas da dominação direta e do poder jurídico colonial, mostram a fragilidade das relações políticas nacionais nas quais, sempre sob momentos graves de crises, o que impera é a convocação da força destruidora de interesses individualistas, sob a garantia, via jurisdição, da conservação dos limites estabelecidos pela razão patrimonialista.

São essas forças, ou melhor, essas relações de poder estabelecidas historicamente que agem e interferem na ação e na participação da sociedade na res publica, contribuindo para que, 
em momentos decisivos de apelo democrático em nosso país, as relações sociais estabelecidas se rompam eliminando o consenso e a ideia de república e fazendo com que a violência lute contra a democracia e o direito. (ARENDT, 2018, p. 17-48).

Uma das maneiras pelas quais se poderia tomar um caminho é o investimento das reclamações teóricas e práticas em direção aos mecanismos internacionais em busca de uma homogeneização dos direitos nas mais vastas regiões do globo. A uniformização dos critérios tais como democracia, estado de direito e legitimidade poderiam ajudar-nos na construção de uma segurança jurídica suficientemente forte a ponto de não se depender de uma vontade estatal arbitrária, ao mesmo tempo um conjunto de regras suficientemente fraco para ser preenchido materialmente de acordo com as variações culturais locais. De todo modo, esse transconstitucionalismo também pode ser um horizonte de perspectiva.

É nesse sentido que Marcelo Neves destaca a maneira pela qual outras ordens jurídicas surgem para enfrentar diversos problemas de natureza constitucional, inclusive de forma divergente da solução estatal. Assim,

O direito constitucional, nesse sentido, embora tenha a sua base originária no Estado, dele se emancipa, não precisamente porque surgiu uma multidão de novas Constituições, mas sim tendo em vista que outras ordens jurídicas estão envolvidas diretamente na solução dos problemas constitucionais básicos, prevalecendo, em muitos casos, contra a orientação das respectivas ordens estatais. Além do mais, surgem permanentemente relações diretas entre Estados para tratar de problemas constitucionais comuns. A exceção, nos dois casos, passou a ser a regra. (NEVES, 2014, p. 206).

A discussão sobre novas ordens jurídicas ou sobre novos direitos também precisa ser compreendida a partir da ideia de comunidade ou de algo que seja comunitário, que também se relaciona ao poder e aos seus usos, reveste-se de importância principalmente quando se pensa as relações entre totalitarismo e democracia, ou seja, quando os polos delimitadores do poder e da violência se aproximam (ARENDT, 2007; 2018; LEFORT, 2011).

Quando se dissemina a discussão sobre a mudança dos paradigmas em nível político e social e sobre as formas alternativas de normatividade a partir de novos sujeitos coletivos de juridicidade, torna-se imperioso recuperar a conceptualização de "comunidade". Ainda que possa carregar um sentido por vezes amplo e difuso, a noção de comunidade implica certo aglomerado social com características singulares, interesses comuns e identidade própria, que, embora inseridos num espectro de relações pulverizadas por consenso/dissenso, interligam-se por um lastro geográfico espacial, coexistência ideológica e carências materiais. (WOLKMER, 2015, p. 292293). 
Fernando Cesar Mendes Barbosa \& José Mauro Garboza Junior

É dessa maneira que consenso e dissenso possuem múltiplas interfaces que se relacionam com os limites da participação democrática (LEFORT, 2011), ora se aproximando das relações estabelecidas pela instituição do poder, ora sendo determinada pela instrumentalização da violência, conforme propôs Arendt (2018).

\section{POLÍTICA E DEMOCRACIA EM NORBERTO BOBBIO}

Portanto, se até o momento precisamos tecer considerações a respeito da violência como um fator que anda junto com o poder político ameaçando-o e ao mesmo tempo constituindo-o, e também, a partir do ponto de vista da história do direito, apresentar considerações a respeito da forma com a qual o direito se dinamiza por uma estatalidade centralista, é preciso insistir neste capítulo/tópico que ambas as operações citadas devem se submeter, se tratadas do ponto de vista eminentemente jurídico, ou ao constitucionalismo ou à democracia.

Se é possível entender a função política do Direito dentro dos critérios que o próprio Estado de Direito estabelece (BOBBIO, 1999; 2006), o que está em jogo é a disputa que acompanha desde o século XIX a vertente liberal do constitucionalismo como potência da liberdade positiva e a vertente social do democratismo como potência dos limites das próprias liberdades (liberdade negativa). Esse jargão somente funciona se consideramos o Estado como o eixo flexível da disputa, isto é, a centralidade estatal é preservada tanto no liberalismo quanto na democracia.

Para além disso, mas ainda em relação à democracia, em sua filosofia política, Norberto Bobbio a compara a partir do liberalismo. Para ele, "Um Estado liberal não é necessariamente democrático: ao contrário, realiza-se historicamente em sociedades nas quais a participação no governo é bastante restrita, limitada às classes possuidoras" (2013, p. 7) e prossegue afirmando que o Estado liberal "se afirma na luta contra o Estado absoluto em defesa do Estado de direito e contra o Estado máximo em defesa do Estado mínimo”. (2013, p. 18).

Ao pensar a democracia e o liberalismo, Bobbio destaca que "como teoria do Estado, o liberalismo é moderno, enquanto a democracia, enquanto forma de governo é antiga". (2013, p. 29). O autor faz uso de um conceito amplo e antigo da democracia, fazendo que esta seja entendida a partir de seu viés imaginário e ideologicamente greco-romano. Trata-se de uma acepção que contrasta com a forma moderna da teoria do Estado que é o liberalismo, em 
conjunto, é possível dizer que ambas relações são assimétricas e, em sua perspectiva, a democracia tem mais a oferecer que o liberalismo.

Assim, a importância da distinção entre liberalismo e constitucionalismo é imprescindível para que continuemos a afirmar um possível direito a não violência, uma vez que o direito sob os domínios do constitucionalismo podem ser alvos de denúncia por parte da liberdade promovida pelo liberalismo e, por sua vez, um direito assentado sob o liberalismo pode sofrer suas críticas e insatisfações a partir da força reguladora típica do constitucionalismo. Se se afirmássemos o necessário vínculo entre ambas as dimensões, não restaria opções de insatisfação aproximando-nos cada vez mais dos modelos autoritários do início do século passado (LEFORT, 2011, p. 51).

Tal distinção ainda nos serve na medida em que as opressões que cada polo eventualmente pode promover estão descoladas do outro lado. Assim, se a opressão do liberalismo a partir de sua forma de governar ofende a maioria da população com suas regras que beneficiam poucos e tendem a promover as desigualdades sociais, ele pode ser enfrentado pela força democrática. Por outro lado, se a opressão democrática das maiorias fere condições básicas e essenciais de um grupo minoritário vulnerável e carente de apoio estatal, a defesa se dá através do liberalismo contra a democracia.

É a partir do estabelecimento de relações como essa que "classificam" a democracia como antiga e o liberalismo como moderno - com toda a carga semântica que cada um dos dois termos carrega - que Bobbio considera que, em certa medida, pode haver compatibilidade entre liberalismo e democracia: "já a democracia moderna não só não é incompatível com o liberalismo como pode dele ser considerada, sob muitos aspectos e ao menos até um certo ponto, um natural prosseguimento". (2013, p. 35).

Apesar disso, essa compatibilidade entre o liberalismo e a democracia assenta-se quando a democracia é compreendida em seu caráter mais procedimental que substancial, ou seja, a democracia tomada como um governo do povo e não para o povo. No entanto, é importante também notar que liberalismo e democracia podem se revelar como realidades opostas, dependendo das concepções políticas que forem utilizadas para definir um e outro. Nesse ponto, Norberto Bobbio esclarece que a problemática da qual se reveste essa relação entre o liberalismo e a democracia relaciona-se com o problema da liberdade e da igualdade, dessa forma, 
Fernando Cesar Mendes Barbosa \& José Mauro Garboza Junior

liberdade e igualdade são valores antitéticos, no sentido de que não se pode realizar plenamente um sem limitar fortemente o outro: uma sociedade liberalliberista é inevitavelmente não igualitária, assim como uma sociedade igualitária é inevitavelmente não-liberal. Libertarismo e igualitarismo fundam suas raízes em concepções do homem e da sociedade profundamente diversas: individualista, conflitualista e pluralista a liberal; totalizante, harmônica e monista a igualitária. (2013, p. 39).

Esse encontro entre a democracia e o liberalismo, explicado a partir dos pressupostos da igualdade e da liberdade apresenta suas possibilidades de convergência por meio da noção de soberania popular, de forma que "Não só o liberalismo é compatível com a democracia, mas a democracia pode ser considerada o natural desenvolvimento do Estado liberal apenas se tomada não pelo lado de seu ideal igualitário, mas pelo lado da sua fórmula política, que é, (...) a soberania popular". (2013, p. 42-43).

Apesar de suas diferenças, o liberalismo se une com a democracia em uma conciliação específica. Pela própria dinâmica entre as liberdades individuais e as garantias sociais, tanto o liberalismo quanto a democracia tendem a se coligar na medida em que uma não o é sem o outro. Isso não quer dizer que todo Estado democrático é um Estado liberal, ou que toda forma de liberdade positiva é já uma forma de liberdade negativa. É a própria perspectiva estatal que organiza essa relação.

No entanto, ainda cabe indagar: se essa relação concilia as prerrogativas do liberalismo e da democracia, isso se daria apenas no nível estatal? Ou melhor, estes termos possuem algum sentido para além do império do Estado de Direito? Há que se decidir por duas respostas.

Se a primeira resposta for uma negativa (não é possível pensar liberalismo e democracia para além do estatal), estaremos vinculados a, no mínimo, duas perspectivas que já confirmamos não estarem adequadas. Uma é a de que existe uma dimensão para além do Estado, e outra de que em cada momento histórico uma forma de resolução ganha a disputa. Nesse caso, o Estado como vencedor da disputa histórica faz questão de se impor e consequentemente limitar seus limites.

Se a outra resposta for positiva, enfim, conseguiremos abrir um horizonte de possibilidades para a reformulação das dimensões dos problemas atuais envolvendo a violência, o poder e a democracia. Ao assumirmos as duas premissas anteriores, podemos falar agora de um investimento dos esforços para situações que contornam os estados, de linhas de forças extraestatais cuja existência mesma já desafia os parâmetros clássicos do pensamento político. 
Essa perspectiva é a que assumimos como uma alternativa possível e plausível diante do cenário construído.

Se a alternativa passa do desmonte das forças monopolistas estatais que continuam a se empenhar em estabelecer-se como os únicos critérios existentes da política como um todo, nossa direção não apontará nem para o constitucionalismo e nem para a democracia. É preciso apontar contra o monopólio do Estado em busca do pluralismo democrático jurídico.

\section{CONSIDERAÇÕES FINAIS}

A relação entre Estado e democracia, distante de ser considerada uma relação de estabilidade, tem sido constantemente ressignificada, caracterizando-se como uma relação de luta de forças, uma relação de poder que se estabelece por meio de tensões entre o poder, entre a violência e entre o direito. Dessa maneira, a ideia de estatalidade e democracia sinaliza para polaridades que também são definidas por meio da força ou da violência.

No segundo capítulo, procuramos definir a violência a partir de Hannah Arendt para contribuir nas discussões acerca de sua classificação e diferenciação entre o poder legítimo e propriamente político, seu caráter antagônico e invencível. A violência sempre deve permanecer como o risco do político, e assim, a comunidade política a todo instante utiliza de suas deliberações para neutralizá-la ou adestrá-la.

No terceiro capítulo, a narrativa histórica percebida como um múltiplo de intenções produto das pequenas relações de poder atestam que a criatividade histórica não deve ser considerada neutra, que as visões de mundo jurídicas dependerão necessariamente das visões de mundo políticas das quais seus participantes (da comunidade) fazem uso. Com isso, queremos mostrar que a estatalidade foi uma das formas vencidas ao longo da história para a resolução e operação de problemas jurídicos. O tempo atual impõe desafios cuja utilização do direito até agora não está conseguindo dar conta justamente pela carga estatal monopolista indicada.

No quarto capítulo, buscamos mostrar como, após a construção popular estatal e social, as disputas políticas devem encaminhar-se para modos de enfrentamentos como fim é a posse momentânea do governo e o respeito pelos adversários políticos. Tentamos demonstrar como a função política do direito está fortemente relacionada a um verdadeiro choque de interesses perpetrado entre uma proposta mais liberal de constitucionalismo e uma proposta mais social do democratismo. 
Fernando Cesar Mendes Barbosa \& José Mauro Garboza Junior

Por fim, foi nesse sentido que procuramos demonstrar como consensos e dissensos agem diretamente na construção de uma relação binária entre estatalidade e democracia, revelando a maneira pela qual o poder, como resultado, do consenso é sempre legítimo ao passo que a violência, além de poder aniquilar o poder consensual, jamais gozará da mesma legitimidade, mas, tão somente, de situações justificadoras do seu uso. Além disso, verificouse que a história do direito constitui um elemento imprescindível na construção de conhecimentos acerca dos ressignificados da relação entre a democracia e a estatalidade ao longo da história, apontando para a insuficiência do monopólio estatal na "construção" do direito.

Finalmente, não se espera com as reflexões aqui apresentadas, ter realizado uma abordagem exaustiva sobre as relações que são estabelecidas com a democracia e a partir dela. Diversamente, a análise realizada evidenciou que ainda há um longo caminho a ser percorrido na construção de uma sociedade mais justa e mais democrática, desafios que só poderão ser atingidos se os apelos democráticos contemporâneos discutidos ao longo deste trabalho forem enfrentados e se os desafios democráticos não forem contornados.

\section{REFERÊNCIAS}

ARENDT, Hannah. Sobre a violência. Tradução de André Macedo Duarte. $9^{a}$ ed. Rio de Janeiro: Civilização Brasileira, 2018.

ARENDT, Hannah. Origens do Totalitarismo. $2^{\text {a }}$ ed. São Paulo: Companhia das Letras, 2007.

ARENDT, Hannah. Eichmann em Jerusalém: uma reportagem sobre a banalidade do mal. $2^{a}$ ed. Lisboa: Tenacitas, 2004.

ARENDT, Hannah. Sobre a revolução. Trad. Denise Bottmann. São Paulo: Companhia das Letras, 2011.

BENJAMIN, Walter. Para uma crítica da violência. In: BENJAMIN, W. Escritos sobre mito e linguagem (1915-1921). Tradução de Susana Kampff Lages e Ernani Chaves; organização, apresentação e notas de Jeanne Marie Gagnebin. São Paulo: Editora 34, 2011.

BOBBIO, Norberto. Liberalismo e Democracia. Tradução de Marco Aurélio Nogueira. São Paulo: Brasiliense, 2013.

BOBBIO, Norberto. “O Positivismo Jurídico" - Lições de Filosofia do Direito. São Paulo: Ícone, 2006.

BOBBIO, Norberto. Teoria do ordenamento jurídico. 10ª ed. Trad. Cláudio de Cicco e Maria Celeste C. J. Santos. Brasília: Universidade de Brasília, 1999. 
BOBBIO, Norberto. Teoria Geral da Política: a filosofia política e as lições dos clássicos. Organizado por Michelangelo Bovero. Tradução de Daniela Beccaccia Versiani. Rio de Janeiro: Campus, 2000.

FOUCAULT, Michel. Microfísica do poder. organização e tradução de Roberto Machado. 4. ed. Rio de Janeiro: Edições Graal, 1984.

FOUCAULT, Michel. Vigiar e punir: nascimento da prisão. Tradução de Raquel Ramalhete. Petrópolis, Vozes, 1987. 288p.

FRASER, Nancy. Rethinking the Public Sphere: A Contribution to the Critique of Actually Existing Democracy. In: Social Text, $\mathrm{n}^{\circ}$. 25/26, 1990, pp. 56-80. Disponível em: <https://www.jstor.org/stable/466240 >. Acesso em: 01 abril 2019.

HABERMAS, 2014. Mudança estrutural da esfera pública: Investigações sobre uma categoria da sociedade burguesa. Tradução: Denilson Luís Werle. 1. ed. São Paulo: Editora Unesp.

HESPANHA, António Manuel. Cultura jurídica europeia: síntese de um milênio. Florianópolis: Fundação Boiteux, 2005.

HESPANHA. António Manuel. Pluralismo Jurídico e Direito Democrático. 2. ed. Lisboa: Amazon, 2016.

LEFORT, Claude. A Invenção Democrática: Os Limites da Dominação Totalitária. Belo Horizonte: Ed. Autêntica, 2011.

NEVES, Marcelo. Transconstitucionalismo. São Paulo: WMF Martins Fontes, 2009.

WEBER, Max. Economia e sociedade: fundamentos da sociologia compreensiva. Tradução de Regis Barbosa e Karen Elsabe Barbosa. Brasília, DF: Editora Universidade de Brasília: São Paulo: Imprensa Oficial do Estado de São Paulo, 1999. 586 p.

WOLKMER, Antônio Carlos. Pluralismo jurídico: fundamentos para uma nova cultura no direito. $4^{\text {a }}$ ed. São Paulo: Saraiva, 2015. 